\title{
Development and Effectiveness Analysis of Science and Gifted Education Program
}

\author{
Woo Suk Jin ${ }^{1}$ \\ ${ }^{1}$ Ph.D., Cooperative Course for Gifted Education, Busan National University, Graduate School, \\ jwsjws@empal.com
}

\begin{abstract}
The purpose of this study is to develop science and gifted education programs in accordance with the national gifted education program standard development procedure established through the Gifted Education Promotion Act. The data in this study were conducted in accordance with the KEDItype model in the third phase of the deep study, and the data of the science gifted program was developed for elementary school students according to the procedure model for developing the national gifted education program. In addition, the effectiveness of the program was analyzed by applying the standard of the national gifted program to the educational field. These studies have shown that the science and gifted programs developed can effectively influence students' development of creative problem-solving skills and science and core competency growth. In order for students to improve their thinking skills and core competencies in gifted education activities, they expect to increase the utilization and effectiveness of science and gifted education programs when systematic learning activities are prepared according to the data development procedures.
\end{abstract}

Keywords: National Gifted Program Standards, Project Learning, Science, Gifted Education, Science, Creative Problem Solving, Science Core Competencies

\section{Introduction}

The national gifted education program standards were initiated by the development of the "National Standard Gifted Education Program Standards" for strengthening the management system of gifted education programs and supporting gifted education sites. However, the programs currently used in the field tend to focus on subject activities such as specific areas and focus on the level of interest of gifted teachers, so there are many overlapping or biased themes every year.

Accordingly, there is educational value for each gifted education institution to develop and apply teaching materials related to gifted education in consideration of the characteristics and conditions of the institution. There are creative activities related to problem discovery by themselves rather than solving a given problem through simple memorization or infusion of knowledge. especially in order to develop educational programs for scientific gifted people[1].

In other words, it is necessary to be interested in scientific exploration activities that enable scientists to explore, experiment, and report questions found in the research world[2].

In addition, the government intends to develop and apply gifted education programs based on national gifted education programs, verify their effectiveness, and utilize basic data to explore educational practical measures.

Received: November 26, 2020; $1^{\text {st }}$ Review Result: January 15, 2021; $2^{\text {nd }}$ Review Result: March 02, 2021 Accepted: March 29, 2021 


\section{Theoretical Background}

\subsection{Definition of Giftedness}

According to Article 2 of the National Gifted Education Promotion Act, "gifted" means a person who needs special education to develop his or her natural potential as a person with outstanding talent. However, the definition and concept of giftedness vary slightly from country to country, and the criteria for distinguishing and educating gifted people vary, so it is very important socially and culturally to define giftedness in education. The concept of giftedness is thought to be different from the scholar's view or from the times, and the six commonly classified definitions of giftedness represent various characteristics of these giftednesses: psychometric definitions, characteristics-based definitions, social needs-based definitions, education-based definitions, special talents definitions, and multi-dimensional.

Among them, the definition based on education is one that focuses on the quality of gifted education. In this category, the United State Office of Education (USOE, 1978), based on a 1972 report submitted by Marland to Congress, is a prime example of what we know. The USOE said, "The gifted is a child who has been judged by experts to be capable of outstanding achievements. Gifted people are children who need more discriminatory educational programs or services than the regular curriculum provides to contribute to themselves and society." This definition has two conditions: 'visibility of potential' and 'demand for differentiated educational services' and is closely related to the quality of gifted education[3].

In addition, gifted education refers to education for gifted children in the contents and methods appropriate to each person's abilities and qualities, as mentioned in the Gifted Education Promotion Act. Based on these studies, it would be necessary to think from a multi-dimensional perspective in understanding gifted children, referring to Renzuli's three-ring model theory, which emphasizes aboveaverage intelligence, high task adherence, and high creativity interactions.

\subsection{Creative Problem-solving Skills}

The process of creative problem solving can be said to include solving a given problem and recognizing and structuring the problem meaningfully in the general problem-solving process. Solving a problem is a creative process that connects concepts, functions, and thinking strategies that the learner already knows in a new way appropriate to a given problem situation[4].

To solve a problem creatively, we first need a clear definition of what the problem is. A problem is defined as a situation in which a person must find a way to reach that goal in order to achieve it[5].

As for what problem solving is, problem solving is a complex interaction of cognitive, emotional, and behavioral processes to adapt to internal or external needs and challenges[6].

Another scholar defined problem solving as discovering solutions to new problems by applying the rules already learned[7].

The integrated view of creativity and problem-solving defined creativity as the ability to generate new, novel, and original outputs from a given or detected problem, and that openness, internal motivation, and proliferation will play an important role in the problem discovery phase[8].

There were also cases where the definition of problem solving was to create a new solution to the problem, including the concept of creativity in problem solving[9].

In the case of Korean scholars, it was called a series of thought activities to achieve desirable goal states by utilizing high-dimensional cognitive abilities and overcoming obstacles associated with a given problem[10]. Troubleshooting is the activity of recognizing the difference between the current state of the troubleshooter and the target state that needs to be reached, and solving the problem is the intellectual and creative ability to resolve these differences quickly and effectively[11]. 
Problem-solving also means the ability of learners to identify and effectively solve problems in problem situations, and to perform them, and to recognize and properly solve problems in daily and social life through creative and logical thinking[12].

The general problem resolution definition identifies the effectiveness and the solution after analyzing the problem situation, but in the creative problem resolution process, the ideas are discovered to find effective solutions, various solutions are found, and in that respect diffuse and convergent thinking are activated simultaneously[13].

The Korea Educational Development Institute (2001) defined creative problem resolution as "a combination of various factors in the problem-solving process, creating useful and original outputs or solutions for problem-solving"[11].

Kim Young-chae[14] explained that creative problem-solving is not just "the process of solving problems by replaying a tested or conventional solution, but by recognizing that there is not one but a variety of solutions and finding the best solution among many solutions."

In other words, creative problem-solving can be defined as the overall process of identifying and restructuring complexly intertwined unstructured creative problems associated with creativity to devise and apply new and original solutions to solve problems.

\subsection{National Gifted Education Program: Science in Elementary and Middle School}

Programs as a teaching plan used in science gifted education should be able to provide opportunities for gifted students to express and utilize their various abilities, such as familiarity with abstraction, excellent concentration and persistence, curiosity about new things, quick understanding and transition[15].

The purpose of science gifted education is to develop scientists as creative leaders of the future by discovering gifted children with excellent abilities and potential. Therefore, "National Gifted Education Program Standards: Elementary and Middle School Science" should reflect the various abilities and characteristics of science gifted students, provide opportunities to maximize their abilities and potential, and support them to develop their qualities and character. This is in line with how to differentiate the national gifted education program: Elementary and middle school science" from the regular curriculum as a program standard for gifted education while maintaining a link with regular science curriculum." The "National Gifted Education Program: Elementary and Middle School Science" established two development categories to reflect the abilities and characteristics of science gifted students, to differentiate them from regular curriculum, and to foster science gifted students as creative scientists. Scientific Literacy for Gifted, which includes acquiring scientific concepts, exploring practicalities, understanding the nature of science, understanding the interrelationship between concepts, and strengthening scientific proficiency and competence to grow into creative scientists.

[Table 1] A Science Gifted Program that Applies the National Gifted Education Program Standards

\begin{tabular}{|c|c|c|c|}
\hline \multirow{2}{*}{$\begin{array}{c}\text { The } \\
\text { learning } \\
\text { stage }\end{array}$} & \multicolumn{2}{|r|}{ Major Class Activities } & \multirow{2}{*}{$\begin{array}{l}\text { Class data and } \\
\text { significance }\end{array}$} \\
\hline & Chash & Teaching-learning activities & \\
\hline $\begin{array}{l}\text { (Basic } \\
\text { Activities) } \\
\text { Problem } \\
\text { recognition } \\
\text { And } \\
\text { Hypothesis } \\
\text { Settings }\end{array}$ & $1 \sim 2$ & $\begin{array}{l}\text { Preparation of self-evaluation sheet for core competency inspection for } \\
\text { science gifted students before educational activities } \\
\text { [Learn about water pollution] } \\
\text { Exploring the Water Quality Using Life in Water } \\
\text { Investigate, classify, and discuss efficient ways to reduce water pollution } \\
\text { by investigating and classifying living things according to water quality; }\end{array}$ & $\begin{array}{l}\text { a study paper } \\
\text { Reading material } \\
\text { PPT } \\
\text { Internet search } \\
\text { environment using } \\
\text { smartphone }\end{array}$ \\
\hline
\end{tabular}




\begin{tabular}{|c|c|c|c|}
\hline $\begin{array}{l}\text { Planning and } \\
\text { Fulfillment }\end{array}$ & $3 \sim 4$ & $\begin{array}{l}\text { [Check water pollution level] } \\
\text { Research and lecture on BOD and COD concepts } \\
\text { Discussing the Concepts of BOD and COD } \\
\text { To measure the degree of pollution in the surrounding stream; } \\
\text { Measure the contamination of the water around our lives; } \\
\text { Take samples of surrounding rivers, measure and analyze water pollution } \\
\text { levels, and compare them to understand each other. } \\
\text { Analyzing BOD and COD measurement method and non-color table of } \\
\text { surrounding river; }\end{array}$ & $\begin{array}{c}\text { Pollution } \\
\text { measurement kit, } \\
\text { non-color table, } \\
\text { Designed water } \\
\text { purifier materials }\end{array}$ \\
\hline $\begin{array}{c}\text { Analyzing } \\
\text { and modeling }\end{array}$ & $5 \sim 6$ & $\begin{array}{l}\text { Making Water Purifier Using Appropriate Technology } \\
\text { Describe and discuss the water purification process and principles; } \\
\text { Explaining the Principles of Water Purifier Using Appropriate Technology; } \\
\text { To envision and design an effective water purifier; } \\
\text { Design water purifier can be manufactured; } \\
\text { Developing problem solutions through the process and experiments of } \\
\text { scientific exploration; }\end{array}$ & $\begin{array}{c}\text { Pollution } \\
\text { measurement kit, } \\
\text { non-color table, } \\
\text { Designed water } \\
\text { purifier materials }\end{array}$ \\
\hline $\begin{array}{l}\text { Discussion } \\
\quad \text { and } \\
\text { Prediction }\end{array}$ & $7 \sim 8$ & $\begin{array}{l}\text { An Analysis of Water Purifier Efficiency Using Appropriate Technology } \\
\text { Conduct your own portable water purifier competition and analyze the water } \\
\text { purification efficiency of portable water purifier; } \\
\text { Logically explain the benefits of your own water purifier; } \\
\text { Analyze and explore the water purification efficiency of your own water } \\
\text { purifier; } \\
\text { To prepare self-evaluation sheet for core competency inspection for science } \\
\text { gifted students after education activities; } \\
\text { Preparation of assessment points for class activities to evaluate how the core } \\
\text { competencies were reflected in the class after the educational activities; }\end{array}$ & $\begin{array}{l}\text { Manufactured water } \\
\text { purifier, } \\
\text { contaminated water, } \\
\text { and pollution } \\
\text { measuring kit }\end{array}$ \\
\hline $\begin{array}{l}\text { (Deepening } \\
\text { activities) } \\
\text { Problem } \\
\text { recognition } \\
\text { And } \\
\text { Hypothesis } \\
\text { Settings }\end{array}$ & $9 \sim 11$ & $\begin{array}{l}\text { Guess what's wrong with the 'Climate Change Tuvalu Disappearing Island' } \\
\text { video. } \\
\text { Find out what's going on in Tuvalu with the picture book, "Tuvalu, you } \\
\text { should've taught Tuvalu to swim." } \\
\text { Watch additional videos and think about why environmental issues were not } \\
\text { resolved well; } \\
\text { Find out how to get people's attention; } \\
\text { Use the battery and post-it to come up with ideas for solving problems; } \\
\text { Sort Post-its to get ideas; } \\
\text { Think about the pros and cons of an idea; } \\
\text { Decide on a good idea by one person and one vote; } \\
\text { Share your feedback with a group presentation; } \\
\text { Play by group using the problem board; }\end{array}$ & $\begin{array}{c}\text { Problem } \\
\text { Presentation Topic } \\
\text { Edition }\end{array}$ \\
\hline $\begin{array}{l}\text { Planning and } \\
\text { Fulfillment }\end{array}$ & $12 \sim 14$ & $\begin{array}{l}\text { The power of 'music' is shown in a video; } \\
\text { To choose a topic that you want to express with music; } \\
\text { To decide what kind of music/topics you want to create } \\
\text { Coding Entries; } \\
\text { To review music-related coding features:; } \\
\text { Create music using coding; } \\
\text { Bringing attention to an example of a "MakeyMakey" work and video; } \\
\text { Connecting the Meki Meki Board to the Entry ; } \\
\text { Instructions on how to create a single circuit by connecting an object to a } \\
\text { maki maki board; } \\
\text { Connecting Maki-Makey to Conductive Objects ; } \\
\text { To verify that your coding works correctly; } \\
\text { To verify that the intention is well expressed in the work you have created; }\end{array}$ & $\begin{array}{c}\text { Life in various } \\
\text { countries }- \text { photos } \\
\text { linked to } \\
\text { environmental } \\
\text { pollution prevention }\end{array}$ \\
\hline
\end{tabular}




\begin{tabular}{|c|c|c|c|}
\hline $\begin{array}{c}\text { Analyzing } \\
\text { and modeling }\end{array}$ & $15 \sim 17$ & $\begin{array}{l}\text { The power of 'music' is shown in a video. } \\
\text { To choose a topic that you want to express with music } \\
\text { To decide what kind of music/topics you want to create } \\
\text { Coding Entries } \\
\text { To review music-related coding features: } \\
\text { Create music using coding } \\
\text { Bringing attention to an example of a "MakeyMakey" work and video } \\
\text { Connecting the Meki Meki Board to the Entry } \\
\text { Instructions on how to create a single circuit by connecting an object to a } \\
\text { maki maki board } \\
\text { Connecting Maki-Makey to Conductive Objects } \\
\text { To verify that your coding works correctly } \\
\text { To verify that the intention is well expressed in the work you have created }\end{array}$ & $\begin{array}{l}\text { MAKEY USE } \\
\text { BOARD }\end{array}$ \\
\hline $\begin{array}{l}\text { Discussion } \\
\text { and } \\
\text { Prediction }\end{array}$ & $18 \sim 20$ & $\begin{array}{l}\text { Watch photos of the activity and video editing interview songs; } \\
\text { Classifying imported objects into conductors and nonconductors; } \\
\text { Make a musical instrument and improvise; } \\
\text { Try to play as you code; } \\
\text { Share your thoughts on the 1-line post-it; } \\
\text { (What was good, what was difficult, what needs to be improved) } \\
\text { To guide you through your follow-up activities; } \\
\text { (Write letters to Tuvalu people + make a promotional video with music and } \\
\text { photos) }\end{array}$ & $\begin{array}{l}\text { Creating a musical } \\
\text { atmosphere. Post-it } \\
\text { interview video }\end{array}$ \\
\hline
\end{tabular}

The developed gifted education program systematically reflects the areas of 'scientific skills' and 'scientific proficiency' presented in the National Gifted Education Program standard, and allows students to experience the thinking process and exploratory approach of scientists themselves. Many countries experiencing water shortages understand how to recycle water using proper technology and design and create creative outputs that can be supplied continuously. As a deep-seated activity, it was planned that it could engage in deep creative thinking activities by making maki-maker activities linked to Tuvalo. In addition, the instruction and learning contents are presented as stages of the scientific exploration process (problem recognition and hypothesis setting, planning and performance, interpretation and modeling, discussion and prediction) so that the entire project can be easily applied. Based on the composition of the National Gifted Education Program proposed by the Korea Educational Development Institute, the KEDI-type deep-seated study model was applied to the scientific field.

\section{Research Methods}

\subsection{Subject to Study}

To test the effectiveness of science and gifted education programs in accordance with the national gifted education program standards, 60 students from a local science gifted class at the K Office of Education in 2019 were set up as subjects of research from March to December.

In order to conduct quantitative and qualitative research on gifted elementary school students, 60 experimental students and 60 comparative students were selected. And I developed a science gifted education program and conducted an effect analysis.

\subsection{Research Tools}

In this study, as an evaluation tool for elementary school students' creative problem -solving, the content of the creative problem-solving process was developed by Isaksen and Treffinger based on the theory of problem understanding, idea generation (creativity, creativity, flexibility, refinement) and 
problem resolution. In addition, as an evaluation tool for science and core competence, 'Early School Science Core Competency Checklist'[16] was used, and science and core competence consisted of five competencies. The core competencies of science gifted students presented in the National Gifted Education Program Standard were studied in both qualitative and quantitative studies before and after gifted students' classes.

These assessment tools were verified by one gifted education expert and two gifted teachers to ensure creativity in solving problems and improving science and core competence, and measured through preexamination, post-examination, and the science core competency checklist components and questions as follows.

[Table 2] Creative Problem-Solving Questionnaire Survey Questionnaire

\begin{tabular}{|c|c|c|c|}
\hline Category & Subarea & Number of questions & Context \\
\hline \hline \multirow{4}{*}{$\begin{array}{c}\text { groups } \\
\text { (Window issues) }\end{array}$} & Problem recognition & 5 & $1,2,3,4,5$ \\
\cline { 2 - 4 } & Information collection & 5 & $11,12,13,14,15$ \\
\cline { 2 - 4 } & Analysis capacity & 5 & $16,17,18,19,20$ \\
\cline { 2 - 4 } & Diffusion & 5 & $21,22,23,24,25$ \\
\cline { 2 - 4 } & Decision & 5 & $26,27,28,29,30$ \\
\cline { 2 - 4 } & Planning power & 5 & $31,32,33,34,35$ \\
\cline { 2 - 4 } & Execution and adventure & 5 & $36,37,38,39,40$ \\
\hline
\end{tabular}

[Table 3] Science and Core Competency Survey Questionnaire

\begin{tabular}{|c|c|c|c|}
\hline Category & Subarea & Number of questions & Context \\
\hline \multirow{5}{*}{$\begin{array}{l}\text { Experimental groups } \\
\text { Comparison groups } \\
\text { (science and core } \\
\text { competency) }\end{array}$} & Autism & 2 & 1,2 \\
\hline & The communication & 2 & 3,4 \\
\hline & Detection & 2 & 5,6 \\
\hline & Window prodigy & 2 & 7,8 \\
\hline & Personality & 2 & 9,10 \\
\hline
\end{tabular}

\subsection{Research Procedure}

\subsubsection{Experimental Design}

To analyze the effect of the developed gifted program on creative problem-solving and science and core competence, the experimental group tested the developed gifted science program on the comparison group.

[Table 4] Experimental Group and Comparison Group Pre-Post Test Method

\begin{tabular}{|c|c|c|c|}
\hline Group & Pretest. & Activities & Protests \\
\hline & Window Problems. & & Window Problems. \\
& (40 questions) & & questions) \\
& Science and Core & & Science and Core \\
& Capabilities. & Capabilities. \\
Experimental groups & (10 questions) & Development programs. & (10 questions) \\
& Scientific Capabilities. & (Project class classes) & Scientific Capabilities. \\
& It is an eight-sentence & & It is an eight-sentence \\
& (quantitative, qualitative, & & (quantitative, qualitative, \\
& class evaluation). \\
\hline
\end{tabular}




\begin{tabular}{|c|c|c|c|}
\hline Comparison groups & $\begin{array}{l}\text { Window Problems. } \\
\text { (40 questions) } \\
\text { Science and Core } \\
\text { Capabilities. } \\
\text { (10 questions) } \\
\text { Scientific Capabilities. } \\
\text { It is an eight-sentence } \\
\text { (quantitative, qualitative, } \\
\text { class evaluation). }\end{array}$ & $\begin{array}{l}\text { Science and Technology } \\
\text { (The theme center class) }\end{array}$ & $\begin{array}{l}\text { Window Problems. } \\
\text { (40 questions) } \\
\text { Science and Core } \\
\text { Capabilities. } \\
\text { (10 questions) } \\
\text { Scientific Capabilities. } \\
\text { It is an eight-sentence } \\
\text { (quantitative, qualitative, } \\
\text { class evaluation). }\end{array}$ \\
\hline
\end{tabular}

\subsubsection{Pre-inspection}

[Table 5] Creative Problem-Solving Homogeneity Test

\begin{tabular}{|c|c|c|c|c|c|c|}
\hline Separate & Group & $\mathrm{N}$ & M & SD & $\mathrm{t}$ & $\mathrm{p}$ \\
\hline \multirow{2}{*}{$\begin{array}{l}\text { Problem } \\
\text { recognition }\end{array}$} & $\begin{array}{l}\text { Experimental } \\
\text { groups }\end{array}$ & 60 & 2.6000 & .81368 & \multirow{2}{*}{-1.805} & \multirow{2}{*}{.076} \\
\hline & Comparison groups & 60 & 3.0333 & 1.03335 & & \\
\hline \multirow{2}{*}{$\begin{array}{l}\text { Information } \\
\text { collection }\end{array}$} & $\begin{array}{l}\text { Experimental } \\
\text { groups }\end{array}$ & 60 & 2.7667 & .85836 & \multirow{2}{*}{-.151} & \multirow{2}{*}{.880} \\
\hline & Comparison groups & 60 & 2.8000 & .84690 & & \\
\hline \multirow{2}{*}{$\begin{array}{l}\text { Analysis } \\
\text { capacity }\end{array}$} & $\begin{array}{l}\text { Experimental } \\
\text { groups }\end{array}$ & 60 & 2.2667 & .86834 & \multirow{2}{*}{-.295} & \multirow{2}{*}{.769} \\
\hline & Comparison groups & 60 & 2.3333 & .88409 & & \\
\hline \multirow{2}{*}{ Diffusion } & Experimental group & 60 & 2.6333 & .92786 & \multirow{2}{*}{-.280} & \multirow{2}{*}{.780} \\
\hline & Comparison groups & 60 & 2.7000 & .91539 & & \\
\hline \multirow{2}{*}{ Decision } & $\begin{array}{l}\text { Experimental } \\
\text { groups }\end{array}$ & 60 & 2.7333 & .90719 & \multirow{2}{*}{.599} & \multirow{2}{*}{.551} \\
\hline & Comparison groups & 60 & 2.6000 & .81368 & & \\
\hline \multirow{2}{*}{$\begin{array}{l}\text { Planning } \\
\text { power }\end{array}$} & $\begin{array}{l}\text { Experimental } \\
\text { groups }\end{array}$ & 60 & 2.6000 & 1.06997 & \multirow{2}{*}{-.665} & \multirow{2}{*}{.508} \\
\hline & Comparison groups & 60 & 2.7667 & .85836 & & \\
\hline \multirow{2}{*}{$\begin{array}{l}\text { Execution } \\
\text { and adventure }\end{array}$} & $\begin{array}{l}\text { Experimental } \\
\text { groups }\end{array}$ & 60 & 2.9000 & .71197 & \multirow{2}{*}{1.907} & \multirow{2}{*}{.061} \\
\hline & Comparison groups & 60 & 2.5333 & .77608 & & \\
\hline \multirow{2}{*}{ Assessment } & $\begin{array}{l}\text { Experimental } \\
\text { groups }\end{array}$ & 60 & 2.8000 & .84690 & \multirow{2}{*}{.294} & \multirow{2}{*}{.770} \\
\hline & Comparison groups & 60 & 2.7333 & .90719 & & \\
\hline \multirow{2}{*}{ Feedback } & $\begin{array}{l}\text { Experimental } \\
\text { groups }\end{array}$ & 60 & 2.8333 & .91287 & \multirow{2}{*}{-.248} & \multirow{2}{*}{.805} \\
\hline & Comparison groups & 60 & 2.9000 & 1.15520 & & \\
\hline
\end{tabular}

All nine window-solving issues have no significant differences between the experimental groups and 
the group, and they appear as $p>.05$. They have been able to find homogeneity in the window problem.

[Table 6] Core Competence Test with Science

\begin{tabular}{|c|c|c|c|c|c|c|}
\hline Separate & Group & $\mathrm{N}$ & M & SD & $\mathrm{t}$ & $\mathrm{p}$ \\
\hline \multirow{2}{*}{ Autism } & $\begin{array}{l}\text { Experimental } \\
\text { groups }\end{array}$ & 60 & 2.13 & 0.87 & \multirow{2}{*}{-.144} & \multirow{2}{*}{0.885} \\
\hline & $\begin{array}{l}\text { Comparison } \\
\text { groups }\end{array}$ & 60 & 2.16 & 0.92 & & \\
\hline \multirow{2}{*}{$\begin{array}{c}\text { The } \\
\text { communication }\end{array}$} & $\begin{array}{l}\text { Experimental } \\
\text { groups }\end{array}$ & 60 & 2.20 & 0.70 & \multirow{2}{*}{0.207} & \multirow{2}{*}{0.840} \\
\hline & $\begin{array}{l}\text { Comparison } \\
\text { groups }\end{array}$ & 60 & 2.25 & 0.72 & & \\
\hline \multirow{2}{*}{ Detection } & $\begin{array}{l}\text { Experimental } \\
\text { groups }\end{array}$ & 60 & 2.13 & 0.87 & \multirow{2}{*}{0.144} & \multirow{2}{*}{0.885} \\
\hline & $\begin{array}{l}\text { Comparison } \\
\text { groups }\end{array}$ & 60 & 2.16 & 0.92 & & \\
\hline \multirow{2}{*}{$\begin{array}{l}\text { Window } \\
\text { prodigy }\end{array}$} & $\begin{array}{l}\text { Experimental } \\
\text { groups }\end{array}$ & 60 & 2.20 & 0.70 & \multirow{2}{*}{-.207} & \multirow{2}{*}{0.840} \\
\hline & $\begin{array}{l}\text { Comparison } \\
\text { groups }\end{array}$ & 60 & 2.25 & 0.72 & & \\
\hline \multirow{2}{*}{ Personality } & $\begin{array}{l}\text { Experimental } \\
\text { groups }\end{array}$ & 60 & 2.25 & 0.72 & \multirow{2}{*}{0.139} & \multirow{2}{*}{0.890} \\
\hline & $\begin{array}{l}\text { Comparison } \\
\text { groups }\end{array}$ & 60 & 2.21 & 0.69 & & \\
\hline \multirow{2}{*}{$\begin{array}{c}\text { Science and Core } \\
\text { Capabilities }\end{array}$} & $\begin{array}{l}\text { Experimental } \\
\text { groups }\end{array}$ & 60 & 2.18 & 0.77 & \multirow{2}{*}{0.030} & \multirow{2}{*}{0.870} \\
\hline & $\begin{array}{l}\text { Comparison } \\
\text { groups }\end{array}$ & 60 & 2.21 & 0.79 & & \\
\hline
\end{tabular}

All five science and key competency subcomponents have no significant differences between the experimental groups and the group, and it appears to be a $\mathrm{p}>.05$. They can see that homogeneity has been secured in science and core competencies.

[Table 7] Pre-examination of the Core Competencies of Science Gifted Children Presented in the National Gifted Education Program Standards

\begin{tabular}{|c|c|c|}
\hline Core competencies & Quality Assessment in PMI Techniques & Self-assessment \\
\cline { 2 - 3 } $\begin{array}{c}\text { 1. Application of Technical } \\
\text { Engineering in Natural } \\
\text { Phenomena }\end{array}$ & $\begin{array}{c}\text { Scientific principles found in various natural phenomena have } \\
\text { been recognized or upgraded by understanding the scientific } \\
\text { principles that have been found in engineering. }\end{array}$ & 3.33 \\
\hline $\begin{array}{c}\text { 2. Consolidation of academic } \\
\text { concepts }\end{array}$ & $\begin{array}{c}\text { By associating science with various disciplines, such as } \\
\text { humities, society, and art, many of them have improved their } \\
\text { ability to comprehensively understand and utilize natural } \\
\text { phenomena. }\end{array}$ & 3.51 \\
\hline $\begin{array}{c}\text { 3. A real-life application of } \\
\text { scientific concepts }\end{array}$ & $\begin{array}{c}\text { There were many responses to science, concept and social } \\
\text { culture using scientific concepts, and said that fun and enjoyable } \\
\text { activities were good in this field. }\end{array}$ & 3.82 \\
\hline $\begin{array}{c}\text { 4. The understanding of high- } \\
\text { tech technology through learning } \\
\text { activities }\end{array}$ & $\begin{array}{c}\text { Science and the concept of science and concept were often used } \\
\text { in state-of-the-art science }\end{array}$ & 3.20 \\
\hline
\end{tabular}




\begin{tabular}{|c|c|c|}
\hline 5. Share communication & $\begin{array}{r}\text { The ability to build and communicate a network of knowledge } \\
\text { groups in preparation for a diversified future society, the ability to } \\
\text { communicate, and the ability to contribute to national and regional } \\
\text { public interest, as well as the ability to contribute to public and } \\
\text { local public interest. I answered that most improvements were } \\
\text { made. }\end{array}$ & $\begin{array}{r}\text { They said that the ability to recognize and define the core values } \\
\text { of both individuals and society, maintain justice, and choose the } \\
\text { information that is needed is the improved ability to choose the } \\
\text { most ethical rational person. There was also. }\end{array}$ \\
\hline 6. Value judgment & $\begin{array}{r}\text { The ability to manage the study's research skills effectively, } \\
\text { according to an internal motivation, set plan, and schedule that can } \\
\text { lead to a deep understanding of self-sufficiency, has improved } \\
\text { dramatically, but many say it is not correct. }\end{array}$ & 3.17 \\
\hline 8. Similar capacity & $\begin{array}{r}\text { There were many stories that the ability to possess, accept, and } \\
\text { express a wealth of sensibilities along with the ability to define the } \\
\text { intellectual activities of the Windows has been enhanced, and the } \\
\text { ability to reflect on emotion has been raised. }\end{array}$ & 3.69 \\
\hline
\end{tabular}

\subsubsection{Experimental Treatment}

The class activities of the experimental and comparative groups were conducted for the same period as the developed gifted program and the general gifted program, and the classes were designed and trained as planned activities.

\subsubsection{Post-inspection}

After conducting science and gifted education program classes developed based on the national gifted program standards, they were conducted using the "Science and Core Competence Questionnaire" for experimental and comparative groups.

\subsection{Data Processing}

The data collected from the survey were statistically processed using the SPSS 23 program, and the following statistical methods were applied:

First, to test the homogeneity of the experimental group and the comparative group before the class was conducted in the experimental group, the independent sample t-test was conducted using the results of the science and core competency survey.

Second, the independent sample t-test was checked to find out the effectiveness of science and gifted education programs developed after conducting experiments through classes.

\section{Research Results}

In this research, experimental studies were conducted to determine whether the developed science and gifted education programs were effective in improving science and core competencies, and the results of the study were as follows.

\subsection{Improve Creative Problem-solving}

In order to compare the differences between the experimental group in the developed science and gifted education program class and the comparative group students in the general gifted science class, the pre-examination secured homogeneity. The results of the test for the enhancement of creative 
problem-solving skills are shown in [Table 8].

[Table 8] Development of Creative Problem-solving Skills t-test Results

\begin{tabular}{|c|c|c|c|c|c|c|}
\hline Separate & Group & $\mathrm{N}$ & M & SD & $\mathrm{t}$ & $\mathrm{p}$ \\
\hline \multirow{2}{*}{$\begin{array}{l}\text { Problem } \\
\text { recognition }\end{array}$} & $\begin{array}{l}\text { Experimental } \\
\text { groups }\end{array}$ & 60 & 4.0667 & .86834 & \multirow{2}{*}{3.091} & \multirow{2}{*}{.003} \\
\hline & $\begin{array}{l}\text { Comparison } \\
\text { groups }\end{array}$ & 60 & 3.2333 & 1.19434 & & \\
\hline \multirow{2}{*}{$\begin{array}{l}\text { Information } \\
\text { collection }\end{array}$} & $\begin{array}{l}\text { Experimental } \\
\text { groups }\end{array}$ & 60 & 3.9333 & 1.14269 & \multirow{2}{*}{3.345} & \multirow{2}{*}{.001} \\
\hline & $\begin{array}{l}\text { Comparison } \\
\text { groups }\end{array}$ & 60 & 2.9333 & 1.17248 & & \\
\hline \multirow{2}{*}{$\begin{array}{l}\text { Analysis } \\
\text { capacity }\end{array}$} & $\begin{array}{l}\text { Experimental } \\
\text { groups }\end{array}$ & 60 & 4.2667 & .73968 & \multirow{2}{*}{4.215} & \multirow{2}{*}{.000} \\
\hline & $\begin{array}{l}\text { Comparison } \\
\text { groups }\end{array}$ & 60 & 3.4667 & .73030 & & \\
\hline \multirow{2}{*}{ Diffusion } & $\begin{array}{l}\text { Experimental } \\
\text { groups }\end{array}$ & 60 & 3.9667 & .99943 & \multirow{2}{*}{4.450} & \multirow{2}{*}{.000} \\
\hline & $\begin{array}{l}\text { Comparison } \\
\text { groups }\end{array}$ & 60 & 2.7333 & 1.14269 & & \\
\hline \multirow{2}{*}{ Decision } & $\begin{array}{l}\text { Experimental } \\
\text { groups }\end{array}$ & 60 & 3.9000 & .95953 & \multirow{2}{*}{2.134} & \multirow{2}{*}{.037} \\
\hline & $\begin{array}{l}\text { Comparison } \\
\text { groups }\end{array}$ & 60 & 3.3333 & 1.09334 & & \\
\hline \multirow{2}{*}{$\begin{array}{c}\text { Planning } \\
\text { power }\end{array}$} & $\begin{array}{l}\text { Experimental } \\
\text { groups }\end{array}$ & 60 & 3.9667 & .96431 & \multirow{2}{*}{3.155} & \multirow{2}{*}{.003} \\
\hline & $\begin{array}{l}\text { Comparison } \\
\text { groups }\end{array}$ & 60 & 3.1000 & 1.15520 & & \\
\hline \multirow{2}{*}{$\begin{array}{c}\text { Execution and } \\
\text { adventure }\end{array}$} & $\begin{array}{l}\text { Experimental } \\
\text { groups }\end{array}$ & 60 & 3.5333 & 1.10589 & \multirow{2}{*}{3.063} & \multirow{2}{*}{.003} \\
\hline & $\begin{array}{l}\text { Comparison } \\
\text { groups }\end{array}$ & 60 & 2.7333 & .90719 & & \\
\hline \multirow{2}{*}{ Assessment } & $\begin{array}{l}\text { Experimental } \\
\text { groups }\end{array}$ & 60 & 3.5000 & 1.19626 & \multirow{2}{*}{2.747} & \multirow{2}{*}{.008} \\
\hline & $\begin{array}{l}\text { Comparison } \\
\text { groups }\end{array}$ & 60 & 2.7000 & 1.05536 & & \\
\hline \multirow{2}{*}{ Feedback } & $\begin{array}{l}\text { Experimental } \\
\text { groups }\end{array}$ & 60 & 4.0333 & .99943 & \multirow{2}{*}{8.863} & \multirow{2}{*}{.000} \\
\hline & $\begin{array}{l}\text { Comparison } \\
\text { groups }\end{array}$ & 60 & 2.0667 & 69149 & & \\
\hline
\end{tabular}

The results of the pre- and post-test scores of scientific creative problem-solving skills show a statistical difference at a significant level. Problem recognition, information collection, analytical ability, diffusion thinking, planning ability, execution and adventure handling, evaluation and feedback were also statistically significant, and decision-making was shown to be significant. 
These results are consistent with Strenberg's (1988) research, which emphasizes exploration processoriented activities for science gifted students, as well as with prior research[17].

\subsection{Scientific Core Capacity Improvement}

In order to compare the differences between the experimental group that took the developed science gifted education program and the comparison group students who took the general gifted science class, the pre-examination secured homogeneity. The results of the kidney t-test of science and core competencies are shown in [Table 9].

[Table 9] Results of a t-test of Science and Core Competencies

\begin{tabular}{|c|c|c|c|c|c|c|}
\hline Separate & Group & $\mathrm{N}$ & M & SD & $\mathrm{t}$ & $\mathrm{p}$ \\
\hline \multirow{2}{*}{ Autism } & $\begin{array}{l}\text { Experimental } \\
\text { groups }\end{array}$ & 60 & 3.43 & 1.27 & \multirow{2}{*}{4.631} & \multirow{2}{*}{.000} \\
\hline & $\begin{array}{l}\text { Comparison } \\
\text { groups }\end{array}$ & 60 & 2.13 & 0.85 & & \\
\hline \multirow{2}{*}{$\begin{array}{c}\text { The } \\
\text { communication }\end{array}$} & $\begin{array}{l}\text { Experimental } \\
\text { groups }\end{array}$ & 60 & 3.20 & 1.15 & \multirow{2}{*}{3.637} & \multirow{2}{*}{.000} \\
\hline & $\begin{array}{l}\text { Comparison } \\
\text { groups }\end{array}$ & 60 & 2.25 & 0.71 & & \\
\hline \multirow{2}{*}{ Detection } & $\begin{array}{l}\text { Experimental } \\
\text { groups }\end{array}$ & 60 & 3.31 & 1.18 & \multirow{2}{*}{4.259} & \multirow{2}{*}{.000} \\
\hline & $\begin{array}{l}\text { Comparison } \\
\text { groups }\end{array}$ & 60 & 2.18 & 0.85 & & \\
\hline \multirow{2}{*}{$\begin{array}{l}\text { Window } \\
\text { prodigy }\end{array}$} & $\begin{array}{l}\text { Experimental } \\
\text { groups }\end{array}$ & 60 & 3.41 & 3.18 & \multirow{2}{*}{4.411} & \multirow{2}{*}{.000} \\
\hline & $\begin{array}{l}\text { Comparison } \\
\text { groups }\end{array}$ & 60 & 2.26 & 0.74 & & \\
\hline \multirow{2}{*}{ Personality } & $\begin{array}{l}\text { Experimental } \\
\text { groups }\end{array}$ & 60 & 3.18 & 1.26 & \multirow{2}{*}{3.413} & \multirow{2}{*}{0.015} \\
\hline & $\begin{array}{l}\text { Comparison } \\
\text { groups }\end{array}$ & 60 & 2.26 & 0.73 & & \\
\hline \multirow{2}{*}{$\begin{array}{c}\text { Science and } \\
\text { Core } \\
\text { Capabilities }\end{array}$} & $\begin{array}{l}\text { Experimental } \\
\text { groups }\end{array}$ & 60 & 3.31 & 1.61 & \multirow{2}{*}{4.07} & \multirow{2}{*}{0.00} \\
\hline & $\begin{array}{l}\text { Comparison } \\
\text { groups }\end{array}$ & 60 & 2.22 & 0.78 & & \\
\hline
\end{tabular}

The science and core competency sections are $\mathrm{p}<3.31$ points for the experimental group and $\mathrm{p}<2.22$ points for the comparison group. It was shown that there were statistically significant differences in levels $\mathrm{p}<.01$ In addition, in four subfactors: autonomy, communication, exploration, and creativity, there were statistically significant differences at level $\mathrm{p}<.01$ and personality was shown to be significant at level $\mathrm{p}<.01$.

Through the above results, science and gifted education programs are more effective in improving science and core competencies than existing programs, and the reason for this result is that students can organize their class activities into systematic activities and develop various core competencies through their own processes. To find out whether these differences are statistically significant, pre- and post-test scores show that scientific exploration programs for elementary science gifted students are effective in 
improving scientific learning motivation and use of scientific research programs in science gifted education is effective.

\subsection{Effects of the National Gifted Education Program on the Improvement of the Core Competencies of the Gifted in Science}

[Table 10] Key Competence Survey Statistics for Science Gifted People

\begin{tabular}{|c|c|c|c|c|c|}
\hline \multirow{2}{*}{ Core Competencies } & \multirow{2}{*}{ Quality Assessment in PMI Techniques } & \multicolumn{2}{|c|}{ Self-assessment } & \multirow{2}{*}{$\begin{array}{r}\text { Impro } \\
\text { vement }\end{array}$} & \multirow{2}{*}{$\begin{array}{c}\text { Class } \\
\text { Assessment }\end{array}$} \\
\hline & & Picture & Post & & \\
\hline $\begin{array}{l}\text { 1. Application of } \\
\text { Technical Engineering in } \\
\text { Natural Phenomena }\end{array}$ & $\begin{array}{c}\text { Scientific principles found in various } \\
\text { natural phenomena have been recognized or } \\
\text { upgraded by understanding the scientific } \\
\text { principles that have been found in } \\
\text { engineering. }\end{array}$ & 3.33 & 4.76 & +1.43 & 4.61 \\
\hline $\begin{array}{l}\text { 2. Consolidation of } \\
\text { academic concepts }\end{array}$ & $\begin{array}{c}\text { By associating science with various } \\
\text { disciplines, such as humanities, society and } \\
\text { art, many of them have improved their } \\
\text { ability to comprehensively understand and } \\
\text { utilize natural phenomena. }\end{array}$ & 3.51 & 4.51 & +1.00 & 4.30 \\
\hline $\begin{array}{l}\text { 3. A real-life } \\
\text { application of scientific } \\
\text { concepts }\end{array}$ & $\begin{array}{l}\text { There were many responses to science, } \\
\text { concept and social culture using scientific } \\
\text { concepts, and said that fun and enjoyable } \\
\text { activities were good in this field. }\end{array}$ & 3.82 & 4.23 & +0.41 & 4,82 \\
\hline $\begin{array}{l}\text { 4. The understanding } \\
\text { of high-tech technology } \\
\text { through learning } \\
\text { activities }\end{array}$ & $\begin{array}{l}\text { Science and the concept of science and } \\
\text { concept were often used in state-of-the-art } \\
\text { science. }\end{array}$ & 3.20 & 3.97 & +0.77 & 4.51 \\
\hline $\begin{array}{c}\text { 5.Share } \\
\text { communication }\end{array}$ & $\begin{array}{c}\text { The ability to build and communicate a } \\
\text { network of knowledge groups in preparation } \\
\text { for a diversified future society, the ability to } \\
\text { communicate, and the ability to contribute to } \\
\text { national and regional public interest, as well } \\
\text { as the ability to contribute to public and } \\
\text { local public interest. Most improvements } \\
\text { were made. }\end{array}$ & 4.17 & 4.69 & +0.52 & 5.00 \\
\hline 6. Value judgment & $\begin{array}{l}\text { They said that the ability to recognize } \\
\text { and define the core values of both } \\
\text { individuals and society, maintain justice, and } \\
\text { choose the information that is needed is the } \\
\text { improved ability to choose the most ethical } \\
\text { rational person. }\end{array}$ & 3.76 & 4.66 & +0.9 & 4.05 \\
\hline 7. Manageability & $\begin{array}{c}\text { The ability to manage the study's } \\
\text { research skills effectively, according to an } \\
\text { internal motivation, set plan, and schedule } \\
\text { that can lead to a deep understanding of self- } \\
\text { sufficiency, has improved dramatically, but } \\
\text { many say it is not correct. }\end{array}$ & 3.69 & 3.92 & +0.23 & 4.23 \\
\hline 8. Similar capacity & $\begin{array}{c}\text { There were many stories that the ability } \\
\text { to possess, accept, and express a wealth of } \\
\text { sensibilities along with the ability to define } \\
\text { the intellectual activities of the Windows has } \\
\text { been enhanced, and the ability to reflect on } \\
\text { emotion has been raised. }\end{array}$ & 3.17 & 4.33 & +1.16 & 4.53 \\
\hline
\end{tabular}

The summary of the results of quantitative, qualitative, and class evaluation questionnaire analyses 
obtained by student responses is shown.

First, the item with the highest rate of increase in pre- and post-evaluation was the item of technical engineering application of natural phenomena. According to the analysis, it was important to develop the method of exploring natural cases and scientific principles in real life in the entire course of the water exploration program using appropriate technology in learning based on national gifted programs. The next item is the ability to accept aesthetics. The creative reconstruction of outputs with the ability to possess, accept, and express rich sensibilities for creative activities is having a lot of influence on students' ability to creatively express outputs with focus in class. It is analyzed that the integrated utilization of academic concepts and ability to judge value also showed a high rate of increase.

Second, technological engineering of natural phenomena was applied, followed by integrated use of academic concepts, aesthetic acceptance, real-life application of scientific concepts, understanding advanced technology through learning activities, and self-management. This seems to have been formed in terms of convergence capabilities, in which the contents learned through scientific programs using appropriate technology are applied elsewhere.

Third, the items with the lowest advance and post evaluation scores were self-management, real-life applications of scientific concepts, communication sharing skills, and understanding of advanced technology through learning activities. The reason why self-management skills are not high after the examination shows students' attitude toward self-management skills. Communication-sharing capabilities and real-life applications of scientific concepts were generally high scores, although the rate of increase was not high. This means that the two core competencies are excellent, which means that they have improved a little more after class, and the overall score is even.

\section{Conclusions and Suggestions}

This study aims to identify the effectiveness of developing and applying science and gifted education programs based on national gifted education program standards to enhance creative problem-solving and science and core competencies. Through this, the need for various educational activities was realized through the development and application of gifted education programs based on the national gifted program standard procedures. In addition to the development and dissemination of programs that are highly utilizable in the field and can strengthen learners' voluntary participation, the study was able to know and practice specific educational contents that foster science and core competencies. The appropriateness of the program is often based on the method of learning gifted professors, and the appropriateness of the program can be used to check or modify the appropriateness of the existing program according to the school or grade level.

In addition, through the criteria used as a tool for qualitative verification and evaluation of gifted education programs, it will be possible to organize and apply them in the form of a guide when planning the program. Through this, it will be able to support the development of professors-learning programs in the field of gifted education as an in-depth program that develops learners' thinking skills based on regular curriculum. Through various case analyses that apply these criteria for national gifted programs, it use can be used as a variety of classes that can be applied to educational sites by supplementing existing programs or converging learning topics. It would be worthwhile to study the process and practices of developing gifted education programs based on these criteria for gifted programs in the field of education. Refining and sharing practical gifted programs that teachers need and students who participate in gifted education can help spread the opportunity to develop desirable gifted professor learning programs.

This study identified the effects of educational activities that reflect the characteristics of programs systematically studied and produced for scientific exploration and activities on scientific creative problem solving and science and core competence cultivation. The findings show that: 
First, the developed science program for elementary science and gifted students was found to be effective in solving scientific creative problems and improving science and core competencies of gifted students.

Second, in science and creative problem-solving sub-factors, the information collection, analysis ability, diffusion thinking, planning ability, execution and adventure handling, evaluation, feedback were statistically significant at $\mathrm{p}<.05$, and the decision making at $\mathrm{p}<.05$, which was found to be effective. This can be attributed to project educational activities that emphasize scientific exploration activities more than decision time.

Third, the developed programs for elementary science and gifted students were found to be effective in improving students' science and core competencies. In science and core competency sub-factors, the autonomy, communication, exploration, and creativity were statistically significant at level $p<.01$ and personality worked at level $\mathrm{p}<.01$.

Based on the findings, the developed programs for elementary science and gifted students are found to be effective in solving creative problems and cultivating science and core competencies, which can be useful for gifted classes at front-line education sites. In particular, the developed program organized the exploration activity stage in a similar way to the scientists' exploration process, linking actual scientific exploration activities and project activities. The following ongoing research is needed to steadily supplement this research in line with the changing science topics, issues and scientific knowledge, and to find ways to foster scientific exploration skills and proficiency of science and gifted students.

First, there are many students who feel difficulty in science education activities due to lack of deep and interesting research-oriented programs for science gifted students as they are not actively applied to the front-line educational sites. Therefore, it will be necessary to follow up on the latest scientific knowledge and content educational methods in which guidance teachers can effectively feedback and guide the various educational activities and needs that students feel in the course of science and gifted education and exploration activities. In addition, research must be conducted on various learning models and educational strategies that allow students to experience the entire process of creative exploration to develop the scientific exploration methods in search of solutions tailored to their level.

Second, since this study developed and studied programs developed at the level of students using the criteria for national gifted education programs for elementary science and gifted students, there may be limitations in analyzing the effectiveness of programs. In addition, the period of use of gifted education programs can be a factor affecting changes in definitive areas such as students' motivation to learn, core capabilities of science departments, and creative problem-solving skills.

In order to compensate for the limitations of this study and to explore ways to foster scientific exploration skills, scientific knowledge and competence among gifted and talented students, the following continuous research is needed. First, many students are studying how to guide and explore science gifted students in developing and utilizing science and gifted education programs, but they are not active in front-line education sites, so there are still insufficient in-depth and fun exploration-oriented programs. Therefore, follow-up research will need to be conducted on educational methods in which guidance teachers can effectively feedback and guide the various educational activities and needs students feel in the course of science and gifted education and exploration activities. In addition, research on various learning models and educational strategies that allow students to experience the entire process of creative exploration to solve problems through research that develops scientific exploration methods by finding solutions at their level. Second, this study may have limitations in analyzing the effectiveness of the program as it analyzes the development of programs developed at the level of students using the criteria for the national gifted education program for elementary science and gifted students. The period of use of gifted education programs can affect changes in students' learning motivations, core competencies of science departments, and creative problem-solving skills, so it is necessary to introduce 
and utilize more systematic mid- to long-term programs.

\section{References}

[1] Yoon-jung Kim, Utilization of Strengths in Project-based Learning: Effects of Feedback Types on Self-directed Learning Skills, Academic Performance, and Learning Satisfaction, Dankook University Graduate School of Education, Master's thesis, (2014)

[2] Hyo-nyeong Lee, Hyun-jun Cho, Theoretical Review on the Meaning and Importance of Autonomous Inquiries for the Gifted in Science Education, Journal of Science Education, (2008), Vol.32, No.2, pp.33-50, DOI : $10.21796 /$ jse.2008.32.2.33

[3] Shin-dong Lee, Dong-il Kim, Sook-hee Park, [Announcement of the 2nd topic] : Methods and Tasks for Distinguishing Gifted Children, The Journal of The Korean Society for the gifted and Talented, (2002), Vol.1, No.1, pp.59-89.

[4] Jung-hyo Kim, Oh-nam Kwon, Development of Mathematical Curriculum for Improving Creative Problem Solving: Focusing on Conceptual Knowledge, Journal of Research in Curriculum Instruction, (1999), Vol.3, No.2, pp.247-264.

[5] M. T. H. Chi, R. Glaser, Problem solving ability. In R. Sternberg(Ed.), Human abilities: An information processing approach, San Francisco: Freeman, (1985), pp.227-257.

[6] P. P. Heppner, C. H. Petersen, The Development and Implications of a Personal Problem-solving inventory, Journal of Counseling Psychology, (1982), Vol.29, No.1, pp.66-75, https://doi.org/10.1037/0022-0167.29.1.66

[7] R. W. Gardner, P. S. Holzman, G. S. Klein, H. P. Linton, D. P. Spence, Cognitive Control: A Study of Individual Consistencies in Cognitive Behavior, Psychological Issue, (1959), Vol.1, No.4, pp.1-186.

[8] K. K. Urban, On the Development of Creativity in Children, Creativity Reseach Journal, (1991), Vol.4, No.2, pp.177191, https://doi.org/10.1080/10400419109534384

[9] John Santrock, Educational psychology (6th ed.), McGraw Hill, (2017)

[10] Soo-jin Park, Elementary School Invention Gifted in Team Problem Solving Learning According to the Degree of Structure of the Problem, Interaction Analysis, Chungnam National University Graduate School, Ph.D. dissertation, (2013)

[11] Seok-jae Lee, Yoo-kyung Jang, Hun-nam Lee, Kwang-yeop Park, A Study on the Development of Life Ability Measurement Tools, Focusing on Communication Skills, Problem-solving skills, and Self-directed Learning Skills, Korea Educational Development Institute, (2003)

[12] Young-ran Jeong, Development and Application of Problem-centered learning (PBL) Packages to Improve Dental Hygiene and Learners' Problem-solving skills, Self-directed Learning Skills, and Communication Skills, Konkuk University Graduate School, Ph.D. dissertation, (2009)

[13] Hae-duk Song, Exploring the Components of Creative Problem Solving and the Principles of Teaching Design, Open Education Research, (2007), Vol.15, No.3, pp.55-73, UCI : G704-001282.2007.15.3.005

[14] Young-chae Kim, Theory and Development of Creativity, kyoyookbook, (2007)

[15] Sung-ik Park, Seok-hee Cho, Hong-won Kim, Ji-hyun Lee, Yeo-hong Yoon, Seok-eon Jin, The Theory of Gifted and Talented Education a History of Education and Science, kyoyookbook, (2003)

[16] Soo-hwan Kim, Jae-sung Ko, Ja-myeon Koo, Hyuk-soon Kwon, Hyuk-il Kwon, Nam-gyun Kim, Dong-ho Kim, Taekyun Kim, Hyun-wook Nam, Sang-woo Park, Young-hee Park, Jong-hong Choi, Byung-jo So, Seung-il Baek, An-seok Park, Jung-yoon Lee, Sung-jin Ham, Kyung-yeon Lee, Sung-hak Han, Na-ae, Bo-kwan Jang, 'Early School Science Core Competency Checklist, Korea Foundation for Science and Creativity, (2014)

[17] Ji-young Kim, Development and Application of Problem-solving Exploration Experiments to Enhance Scientific Creativity of Science Gifted Children, The Korean National University of Education, Master's thesis, (2007) 